\title{
French researchers kick up a storm over CNRS 'reforms'
}

[PARIS] Draft plans for a major overhaul of France's Centre National de la Recherche Scientifique (CNRS), Europe's largest fundamental research agency, have run into a storm of protest from labour unions representing scientific staff.

The agency, which has 27,000 staff, currently operates primarily through its own nationwide network of laboratories. The government's proposals put it on the road to becoming a funding agency for universitybased research. The changes would include giving universities joint responsibility for the running of CNRS laboratories.

CNRS funds would be opened up to bidding from competing university research groups. The Ministry of Research argues that such changes, which were outlined to the board of directors of CNRS two weeks ago, will lead to greater efficiency in the way research is carried out.

But the unions have condemned the pro-

posed changes as a recipe for "dismantling" the agency. This view appears to have the tacit backing of many top-level CNRS managers. Criticizing the lack of consultation with other interested parties, the unions have promised that they will fight the reforms "to the bitter end".

The unions' reaction is based on a leaked draft of proposals that have been drawn up by Edouard Brezin, a physicist at the Ecole Normale Supérieure in Paris, who is president of the board of CNRS.

An apparent desire to shift control of research from the CNRS to the universities was reflected in the text by proposed changes to the agency's statutes that would place it not only under the jurisdiction of the "ministry responsible for research," as in the past, but also under the ministry responsible for "higher education".

And, rather than keeping its powers to "create" laboratories and manage research

\section{Universities to get more control of biomedicine}

[PARIS] A reform of the French national biomedical agency INSERM that was abandoned during the summer is set to be resuscitated by the government, with the release of a new decree expected by the end of the year.

The old plan met opposition from unions representing researchers (see Nature 395, 630; 1998). The new reforms, which are also likely to meet opposition, mirror those proposed for the Centre National de la Recherche Scientifique (see above), with INSERM having to share control of its laboratories with the universities. A formal contract between INSERM, the Ministry of National Education, Research and Technology, and the Conference of University Vice-chancellors will set out the common strategic goals of joint groups of university and INSERM researchers.

The new arrangements will mean an influx of university researchers into INSERM laboratories, which

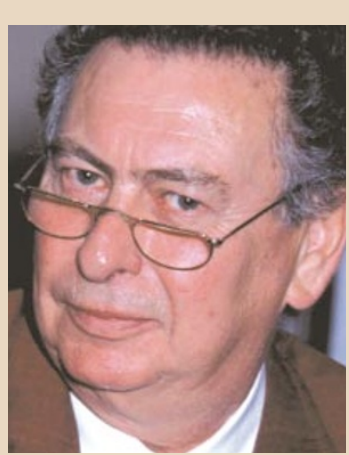

Griscelli: wants to open doors for university researchers.

are at present independent of universities. Around 80 university laboratories will also be given INSERM status over the next five years, according to Claude Griscelli, the agency's director general.

Griscelli says that the new reform will integrate the agency's research activities into a broad national strategy for the life sciences, being drafted by a ministerial committee, that will include all the research organizations and universities.

Ultimately, Griscelli sees INSERM being built around the so-called Instituts
Fédératifs de Recherche (IFR). These create a critical mass in particular scientific areas by bringing together local scientists from the various research agencies, hospitals and universities, forming loose federations of laboratories.

Griscelli plans for around 15 of the 70 IFRs so far created to become full-blown research institutes. Each would have around 300 staff, and would share large facilities, such as transgenic knock-out mice laboratories. Another layer of IFR's would form national networks in particular research areas such as ageing and opthamlogy.

Griscelli also wants to shake up research funding by shifting financing from laboratories to grants awarded to individual groups, based on competitive proposals.

INSERM's research itself will in future be oriented towards medical applications of genome research. according to Griscelli.

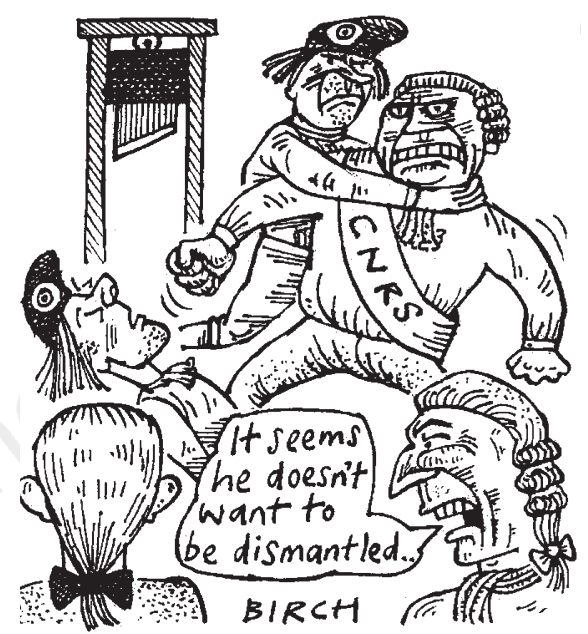

nationally, the text describes the agency's new role as "recognizing and subsidizing" research entities within universities, and other bodies including private companies.

The agency would no longer exert full control over its laboratories, but would exercise joint responsibility for them with the laboratory's parent university. Its responsibility for constructing and managing big science facilities would also disappear. This function, according to ministry sources, would be assumed by the ministry itself.

The chairpersons of six sections of the CNRS's national committee - the body that evaluates all CNRS laboratories and shapes the agency's research priorities — have said they will resign unless the draft decree is revoked, arguing that it threatens to damage "the whole of French research".

The unions' argument that the changes would turn CNRS into little more than a research council is disputed by both Brezin and Vincent Courtillot, principal adviser to Claude Allègre, the minister for national education, research and technology.

They argue that the plan merely represents a further step in a process of closer integration of the agency into the university system that has been under way ever since the first CNRS laboratories associated with universities were created in 1966.

Brezin and Courtillot assert that the text is preliminary and open to debate. Indeed, late last week Brezin issued a revised text, taking into account some of the concerns expressed by the unions and researchers. "The draft text was not written in stone," says Brezin.

Courtillot argues that, although "the unions would prefer to talk at length about general problems first, we think it is better to show a text and get reactions," adding that 
"we really are open and will listen to changes".

One initial proposal that has already been modified is that CNRS would be deprived of the authority to create laboratories, such as those on its campuses at Gif-sur-Yvette on the outskirts of Paris. The revised decree allows for the creation of CNRS laboratories, but these would be the exception. "We are not against CNRS opening new labs, but as a general rule it should take place in discussions with universities," says Courtillot.

The major point of contention over the draft decree concerns the balance of forces between the agency and the universities, a topic with a long history. The agency was created in 1939 to compensate for the weak research base in the universities. Indeed, today the only French universities carrying out international-level research are those with large teams of CNRS researchers.

Many researchers say that university science is still weak, and that it would be premature to increase their power over CNRSfinanced research. Observers argue that French universities tend to put student and local needs first, and cannot properly define or evaluate national research strategies.

The vice-chancellors and the scientific bodies within universities are elected, and this democracy is said to generate a lack of competitiveness. In contrast, the CNRS has rigorous evaluation mechanisms and a reputation for putting scientific excellence first.

A reform of the university system is a prerequisite for any profound reform of CNRS, assert several observers. They argue that, given that university researchers are civil servants, a university laboratory winning a grant would not be freely able to hire researchers, making the idea of a research council meaningless within a French context.

Courtillot agrees that it would be premature to transform CNRS into a research council along the lines of the US National Science Foundation or the UK research councils. But he says the government wants the CNRS to move in this direction, and that the universities should ultimately be the major players in French research.

Courtillot concedes that many universities are not yet capable of taking over responsibilities from the agency, but says that others are ready, and that more will be in time. "In 1988 , less than ten of the then 80 French universities were in a position to have their own research policies, but now 40 of the 100 universities are able to do so," he says.

Another ministry proposal is to replace the current system of funding laboratories with one in which individual teams would be financed on the basis of competitive proposals. The idea, says Courtillot, is to blur the boundaries between the institutions, with teams from different research agencies and universities uniting to form new entities and to seek joint project funding. DeclanButler

\section{Japan's universities resist plan for greater autonomy}

[TOKYO] A bid by the Japanese government to transform national universities into semiautonomous institutions is meeting strong resistance both from leading academics and from the Ministry of Education, Science, Sports and Culture (Monbusho).

Last December, a proposal to change the status of the nation's two leading universities - Tokyo University and Kyoto University was omitted from the final version of the government's administrative reform plan (see Nature 389, 897; 1997). But it has resurfaced since the appointment of the new prime minister, Keizo Obuchi, who has pledged to carry out drastic reorganization of Japan's administration.

The administrative reform plan, which originally targeted national research institutes attached to government ministries and agencies (see Nature 395, 211; 1998), will now also target some of the national universities — including Tokyo and Kyoto.

But the plans are running into strong opposition. Last week Leo Esaki, the Nobel prizewinner and former president of Tsukuba University, said that increased autonomy and drastic changes in their management systems could have negative effects on the universities.

"Given the Japanese universities' lack of competitiveness and management skills, turning them into semi-autonomous bodies with administrative independence will only make things chaotic," said Esaki. He argued

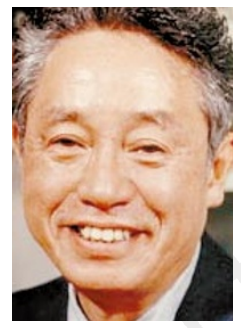

that universities needed instead to begin reforms at a fundamental level, such as introducing a proper system of peer review.

Meanwhile, the Council on University Education, chaired by Akito Esaki: warning of Arima, the education negative effects. minister and former president of Tokyo University, last week announced plans to set up an independent body to assess the performance of national universities.

The move is seen as a bid to resist the government's plans, including external evaluation of the universities' performance every three to five years, by indicating the universities' willingness to increase their effectiveness without the government's restructuring. They argue it will damage both education and research.

Although the government hopes to finalize its reorganization plans by next January, many predict that Monbusho and the universities will not give in, and may try to generate sufficient political opposition for the government to back down.

But some university researchers support the plans, arguing that the national universities' aversion to greater autonomy hinders the spread of venture businesses and industry/university collaboration. AsakoSaegusa

\section{US Congress rebuffs data copyright law}

[WASHINGTON] Critics of proposed legislation that would assign sweeping copyright protection to commercial online databases scored a victory last week when the US Congress passed a bill with the controversial measure stripped out.

Organizations including the American Association for the Advancement of Science and the Association of Research Libraries (ARL) and the Institute of Electrical and Electronics Engineers had been lobbying for months against the legislation, which was sponsored by Representative Howard Coble (Republican, North Carolina) and Senator Rod Grams (Republican, Minnesota).

The proposed change in copyright law, its opponents say, would stifle the flow of scientific information by granting broad and vaguely defined proprietary rights to data that are now exchanged freely (see Nature 394, 410; 1998).

When the measure moved easily through the House of Representatives in May and was then folded into a larger copyright bill on a fast track for passage, "the visibility of the issue was heightened", according to Prudence Adler of the ARL. An intensive letter-writing and lobbying campaign led to House and Senate negotiators dropping the database provision from the larger copyright bill earlier this month.

Around 50 companies and associations, representing a range of political views and interests, weighed in against the database clause. Several federal agencies also pointed out potential constitutional problems.

By the time of the vote, 15 senators urged that the database clause be dropped because it had not been debated thoroughly and serious disagreements remained.

But Judiciary Committee chairman Orrin Hatch (Republican, Utah) and other Republican leaders promised the bill's sponsors that the database issue will get an early hearing when a new Congress returns to Washington in January. Tony Reichhardt 